\title{
Role of brown adipose tissue in body temperature control during the early postnatal period in Syrian hamsters and mice
}

\author{
Ayumi TSUBOTA ${ }^{1)}$, Yuko OKAMATSU-OGURA ${ }^{1) *}$, Jussiaea Valente BARIUAN ${ }^{1 \text { ), }}$ \\ Junnosuke MAE ${ }^{1)}$, Shinya MATSUOKA ${ }^{1)}$, Junko NIO-KOBAYASHI'), \\ Kazuhiro KIMURA ${ }^{1)}$ \\ 1)Laboratory of Biochemistry, Faculty of Veterinary Medicine, Hokkaido University, Sapporo, \\ Hokkaido 060-0818, Japan \\ 2)Laboratory of Histology and Cytology, Faculty of Medicine and Graduate School of Medicine, \\ Hokkaido University, Sapporo, Hokkaido 060-8638, Japan
}

J. Vet. Med. Sci.

81(10): 1461-1467, 2019

doi: 10.1292/jvms.19-0371

Received: 7 July 2019

Accepted: 20 August 2019

Advanced Epub:

6 September 2019

\begin{abstract}
Brown adipose tissue (BAT) contributes to non-shivering thermogenesis and plays an important role in body temperature control. The contribution of BAT thermogenesis to body temperature control in a non-cold environment was evaluated using developing hamsters. Immunostaining for uncoupling protein 1 (UCP1), a mitochondrial protein responsible for BAT thermogenesis, indicated that interscapular fat tissue had matured as BAT at day 14 . When pups were placed on a thermal plate kept at $23^{\circ} \mathrm{C}$, the body surface temperature decreased in day 7 - and 10-day-old pups but was maintained at least for $15 \mathrm{~min}$ in 14-day-old pups, indicating that hamsters are unable to maintain their body temperature until around day 14 even in a non-cold environment. Body temperature maintenance was also evaluated in UCP1-deficient mice. BAT analysis showed that the UCP1 protein level in Ucp $1^{+/-}$Hetero mice was $61.3 \pm 1.4 \%$ of that in wild-type (WT) mice and was undetected in $U c p 1^{-1-}$ knockout (KO) mice. When 12-day-old pups were place on a thermal plate at $23^{\circ} \mathrm{C}$, body surface temperature was maintained for at least $15 \mathrm{~min}$ in WT and Hetero mice but gradually dropped by $2.4 \pm 0.2^{\circ} \mathrm{C}$ in $15 \mathrm{~min}$ in $\mathrm{KO}$ mice. It is concluded that BAT thermogenesis is indispensable for body temperature maintenance in pups of hamsters and mice, even in the non-cold circumstances. The early life poikilothermy and the later acquirement of homeothermy in hamsters may be because of the postnatal development of BAT.

KEY WORDS: body temperature, brown adipose tissue, model animal, thermogenesis, uncoupling protein 1
\end{abstract}

Brown adipose tissue (BAT) contributes to non-shivering thermogenesis and plays an important role in the control of body temperature $[4,5,10]$. The thermogenic function of BAT is mediated by uncoupling protein 1 (UCP1), which is located in the mitochondrial inner membranes of brown adipocytes. The thermogenic function of UCP1 is regulated through the sympathetic nervous system. Norepinephrine released from nerve ends activates $\beta$-adrenergic receptors on the cell membranes of brown adipocytes, resulting in the sequential activation of enzymes including adenylate cyclase, protein kinase A, and hormone-sensitive and adipose triglyceride lipase. Fatty acids liberated from triglycerides activate the uncoupling activity of UCP1. When activated, UCP1 dissipates the proton gradient without generating ATP, resulting in the expenditure of this energy as heat.

BAT thermogenesis is particularly important in a cold environment. Cold stimulation activates BAT-UCP1 through the pathway mentioned above, and BAT thermogenesis, in addition to shivering, contributes to the maintenance of body temperature. Indeed, mice deficient in UCP1 fail to maintain body temperature in cold environment [6]. However, UCP1-knockout (KO) mice can acclimate to cold circumstances by enhancing compensatory mechanisms of non-shivering thermogenesis independent of UCP1, such as sarcolipin- and SERCA-dependent thermogenesis in muscle and adipose tissue, respectively [3, 9, 22, 23].

Since mammals experience the rapid decrease in environment temperature after delivery from the womb uterus, it is assumed that BAT thermogenesis has an indispensable role in pups, especially at birth and during the weaning period. On the other hand, BAT develops in a different manner depending on the species [4]. In precocial animals, BAT development is completed before 
the birth, and fully functional BAT expressing UCP1 actively starts to produce heat immediately after the birth [1, 20]. In altricial newborns, BAT is still immature at birth and is recruited during the first several days after birth, possibly triggered by the decrease in the ambient temperature at birth $[8,13,15]$. Syrian hamsters have a quite unique BAT development pattern in that the newborn hamsters at birth do not have typical BAT, which postnatally develops during the suckling period [21]. Recently, we reported that interscapular fat, where BAT is located in most mammals, mainly consists of white adipocytes at birth, but that brown adipocyte progenitors appear postnatally within the tissue and differentiate into brown adipocytes [16]. In the context of UCP1 protein expression and histology, BAT development is completed by 16-days of age in hamsters. Ambient temperature seems to be important for the progression of the BAT development process: the proliferation of brown adipocyte progenitor and endothelial cells, differentiation of the progenitor cells, and UCP1 expression were suppressed at thermoneutral condition [14].

Thus, in some species, fully-functional BAT is formed after birth, and the contribution of BAT thermogenesis to the maintenance of body temperature in neonates, especially in non-cold conditions, is not clear. Although the shivering capacity seems to be rather low in neonates [2], pups huddle in the nest with their siblings and are usually covered by their dam, and this behavioral regulation may possibly be enough to maintain body temperature. On the other hand, it was reported that newborn hamsters behave like poikilothermic animals and that their body temperature is similar to the ambient temperature especially in a cold environment $[7,19]$. However, it is unknown if the poikilothermy in early life and the acquisition of homeothermy thereafter is related to the postnatal development of BAT. Therefore, in this study, we evaluated the contribution of BAT thermogenesis to body temperature control in a non-cold environment using developing hamsters.

\section{MATERIALS AND METHODS}

\section{Animals}

The experimental procedures and the care of the animals were approved by the Animal Care and Use Committee of Hokkaido University and were conducted in an animal facility approved by the Association for Assessment and Accreditation of Laboratory Animal Care International. Parental Syrian hamsters were purchased from Japan SLC (Hamamatsu, Japan). UCP1-KO (Ucp $1^{-/}$) mice were kindly provided by Dr. L. Kozak (Pennington Biomedical Research Center, Baton Rouge, LA, U.S.A.). All Ucp $1^{+/+}$ wild-type (WT) mice were C57BL/6J strain. Animals were housed in plastic cages within an air-conditioned room at $24^{\circ} \mathrm{C}$, with a 12:12 hr light:dark cycle. They were given free access to laboratory chow (Oriental Yeast, Tokyo, Japan) and tap water. Male and female mice or hamsters were mated by putting females into the cages of males for 1 week. At the indicated day, pups were used for the surface temperature measurement or were euthanized using carbon dioxide, and the fat tissues of the interscapular depot were immediately removed and weighed. Tissue specimens were fixed in 10\% buffered formalin for histological examination or western blotting. In hamster experiment, 4 hamsters from 2 dams were used for each experiment group, and the litter size of dams was 6 to 7. For mouse experiment, KO mice and their WT and hetero littermates from 4 dams were used, and the litter size of dams was 5 to 7 . Each animal was used only once and not repeatedly used to avoid the induction of compensatory thermogenic mechanism.

\section{Measurement of body surface temperature of pups}

At the indicated day, pups were taken from the nest and put on a plate kept at $23^{\circ} \mathrm{C}$. The surface temperature was monitored every $1 \mathrm{~min}$ for $15 \mathrm{~min}$ by infrared camera (FLIR ONE; Flir Systems Inc., Portland, OR, U.S.A.) placed at a height of $25 \mathrm{~cm}$ from the plate. The maximum body surface temperature of each pup was quantified using FLIR software (Flir Systems Inc.).

\section{Histological analysis}

Tissue specimens that were fixed in $10 \%$ buffered formalin were embedded in paraffin according to the conventional method, cut into 4- $\mu \mathrm{m}$-thick sections, and stained with hematoxylin and eosin (HE). Other sections were deparaffinized and then incubated with $0.3 \%$ hydrogen peroxide in methanol to block endogenous peroxidase. After being washed in phosphate-buffered saline, the slides were incubated for $1 \mathrm{hr}$ with 10\% normal goat serum and then with the primary antibody for UCP1, a kind gift from Dr. Teruo Kawada (Kyoto University), overnight at $4^{\circ} \mathrm{C}$. Slides were washed and incubated with biotinylated anti-rabbit secondary antibody for $60 \mathrm{~min}$, followed by incubation with an avidin-biotin-peroxidase complex (Nichirei, Tokyo, Japan) and visualization with 3,3'-diaminobenzidine (Thermo Fisher Scientific, Gaithersburg, MD, U.S.A.) and observed under a light microscope. Photographs taken from the UCP1-immunostained sections were analyzed in Image J (http://imagej.nih.gov/ij/), and the UCP1-positive area in the sections was calculated.

\section{Western blotting}

Tissue specimens were homogenized in Tris- EDTA buffer (10 mM Tris and $1 \mathrm{mM}$ EDTA, pH 7.4). After centrifugation at $800 \times g$ for $10 \mathrm{~min}$ at $4^{\circ} \mathrm{C}$, the supernatant was obtained as total protein, and used to determine the UCP1 and actin content by western blotting. Protein was separated by SDS-PAGE and transferred to a polyvinylidene fluoride membrane (Immobilon; Millipore, Tokyo, Japan). After blocking with 5\% skim milk (Morinaga Milk Industry Co., Tokyo, Japan), the membrane was incubated overnight at $4^{\circ} \mathrm{C}$ with primary antibodies for UCP1 or actin (Sigma-Aldrich Fine Chemical, St. Louis, MO, U.S.A.). The bound antibody was visualized with the enhanced chemiluminescence system (Amersham, Little Chalfont, Bucks, U.K.) using horseradish peroxidase-linked goat anti-rabbit immunoglobulin (Zymed Laboratories, San Francisco, CA, U.S.A.) for the detection of UCP1 or horseradish peroxidase-linked goat anti-mouse immunoglobulin (Jackson Immunoresearch Laboratories, West Grove, PA, U.S.A.) for the detection of actin. 


\section{Data analysis}

Values are expressed as mean \pm SE. Statistical analyses were performed using Student's $t$ test or one-way or two-way analysis of variance (ANOVA) followed by the Tukey's honestly significant difference (HSD) post-hoc test.

\section{RESULTS}

First, we analyzed interscapular fat tissue during the postnatal growth period in hamsters (Fig. 1A). The body length increased $\sim 1.5$-fold from day 7 to day 14 because of growth. The interscapular fat tissue was white in color at day 7 and it changed gradually to brown by day 14 (Fig. 1B). Similar to the postnatal day-dependent increase in body weight (Fig. 1C), the weight of interscapular fat increased and was 2-fold heavier at day 14 compared to day 10, whereas the difference in fat weight between day 7 to day 10 was not statistically significant (Fig. 1D). The ratio of interscapular fat weight to body weight was not changed among the three ages (Fig. 1E).

Histological analysis showed that most of the interscapular fat was occupied by white adipocytes containing unilocular lipid droplet at day 7 (Fig. 2A). Islet-like clusters of progenitor cells without lipid droplets were surrounded by white adipocytes at day 10, and brown adipocytes containing multilocular lipid droplets were the major type of cells in the tissue at day 14. Immunostaining for UCP1, a mitochondrial protein responsible for BAT thermogenesis, revealed that interscapular fat tissue at day 14 had matured as BAT (Fig. 2B). Some of the cells in the progenitor cluster at day 10 were immunoreactive with the anti-UCP1 antibody; however, the UCP1-positive area was low at $18 \pm 3.9 \%$ (Fig. 2C).

To examine the hamster pups' ability to maintain body temperature, the body surface temperature of the pups was monitored using a thermal camera (Fig. 3A and 3B). When pups were taken from the nest where their dam and siblings were gathered, their initial body surface temperature was around $38^{\circ} \mathrm{C}$ and not statistically different irrespective of postnatal day, although it tended to become higher with increasing postnatal time (Fig. $3 \mathrm{C}$ ). When pups were placed on a plate kept at $23^{\circ} \mathrm{C}$, the surface temperature of the day 7 pups gradually decreased from $37.6 \pm 0.2^{\circ} \mathrm{C}$ to $31.0 \pm 0.4^{\circ} \mathrm{C}$ in $15 \mathrm{~min}$ (Fig. 3B). A gradual drop in surface temperature was also observed in day 10 pups, and the change of temperature in 15 min was not different between day $7\left(6.5 \pm 4.4^{\circ} \mathrm{C}\right)$ and

A

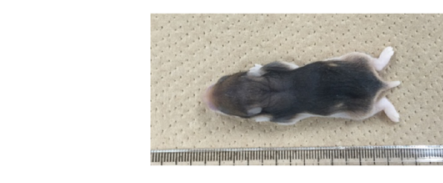

Day 10

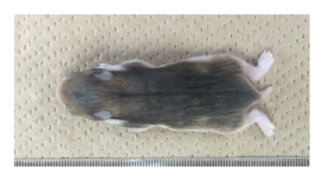

Day 10

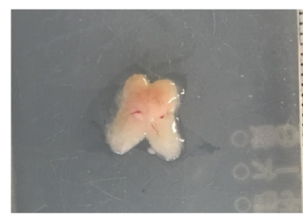

C

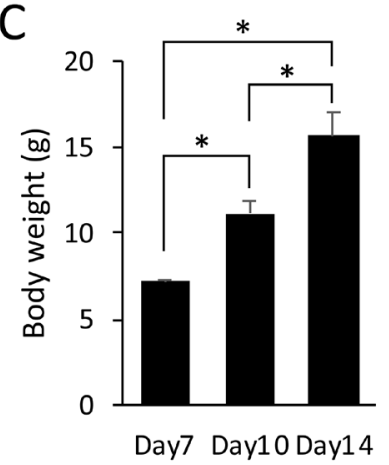

D

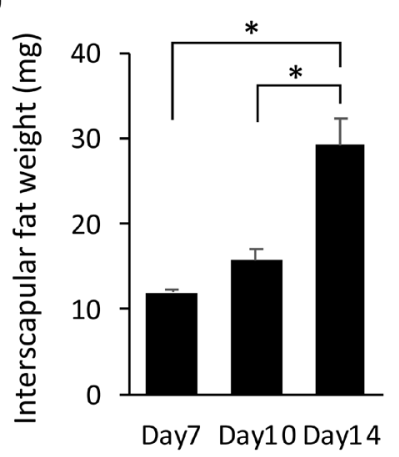

Day 14

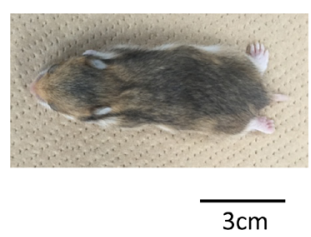

Day 14

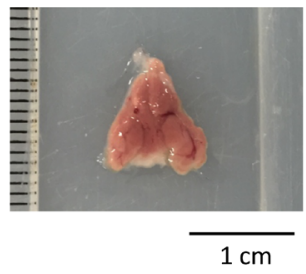

E

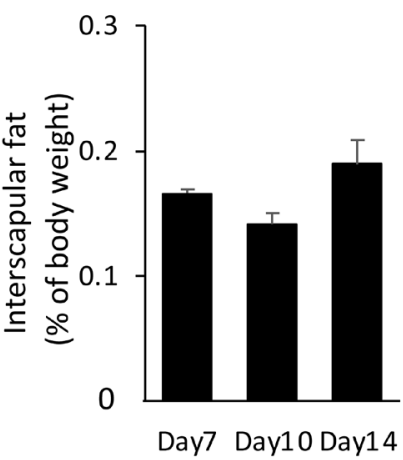

Fig. 1. Gross examination of interscapular fat of 7 to 14-day-old hamsters. Syrian hamsters were born and bred at $23^{\circ} \mathrm{C}$. Representative gross images of hamsters (A) and the interscapular fat tissue (B) on postnatal days 7, 10, and 14 are shown. Body weights (C) and interscapular fat tissue weights (D) were measured and fat tissue weights is expressed as a $\%$ of body weight (E). Values are expressed as mean $\pm \mathrm{SE}(\mathrm{n}=4 \mathrm{per}$ group, one-way analysis of variance followed by the Tukey's honestly significant difference post-hoc test, $* P<0.05$ ). 
A

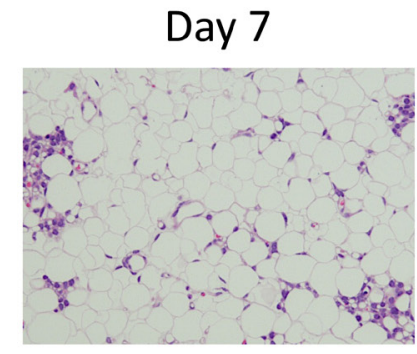

B

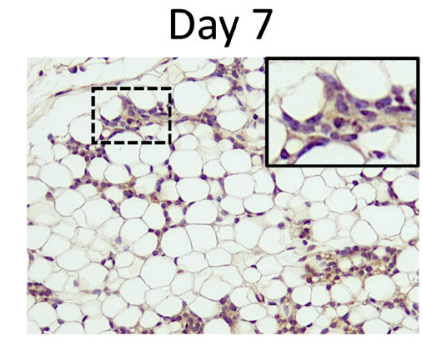

Day 10

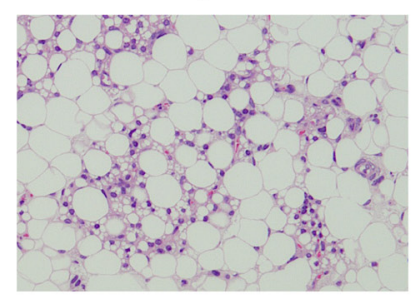

Day 10

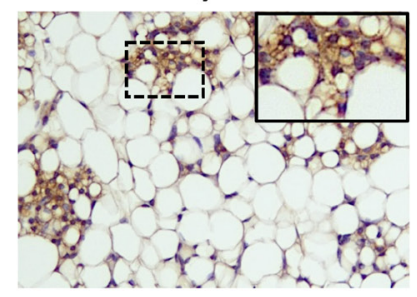

C

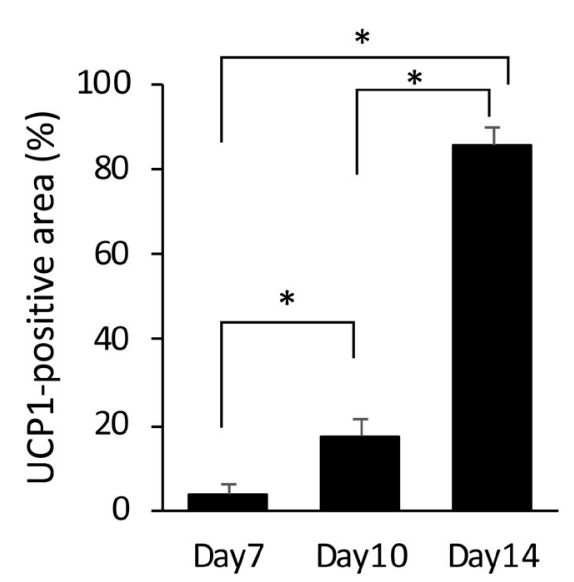

Day 14

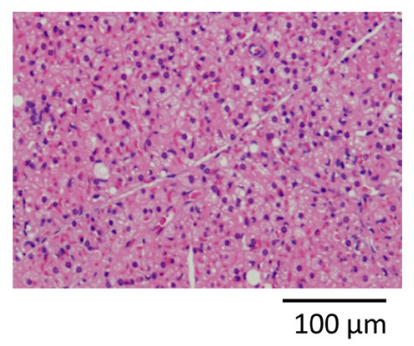

Day 14

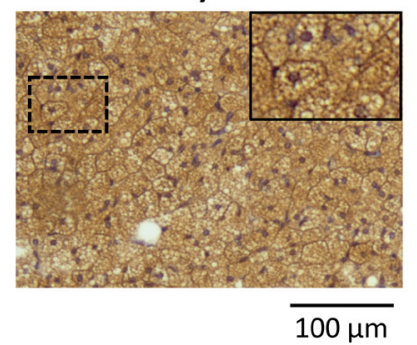

Fig. 2. Histological examination of interscapular fat of 7 to 14-day-old hamsters. Interscapular fat tissues were obtained from 7-, 10-, 14-day-old Syrian hamsters. Interscapular fat sections were stained with hematoxylin and eosin (A) or antibodies against Uncoupling protein 1 (UCP1) (B). The insets in B show magnified views of the area in the dotted square. The UCP1-positive area was quantified (C). Scale bar: $100 \mu \mathrm{m}$. Values are expressed as mean \pm SE ( $\mathrm{n}=4$ per group, one-way analysis of variance followed by the Tukey's honestly significant difference post-hoc test, $\left.{ }^{*} P<0.05\right)$.

day $10\left(4.4 \pm 0.9^{\circ} \mathrm{C}\right)$ (Fig. 3D). In contrast, day 14 pups maintained their temperature for 15 min (Fig. 3C) and the change of temperature was as small as $0.7 \pm 0.8^{\circ} \mathrm{C}$. These results indicate that hamsters are unable to maintain their body temperature until around day 14 even in a non-cold environment.

To evaluate the role of BAT thermogenesis in the maintenance of body temperature in pups more directly, we used mice deficient in UCP1. Body weights at postnatal day 12 were similar among the three genotypes: Ucp $1^{+/+}$(WT), Ucp $1^{+/-}$(Hetero), and $U c p 1^{-/-}$ (KO) mice (Fig. 4A). Western blot analysis of BAT revealed that the UCP1 protein level in Hetero mice was $61.3 \pm 1.4 \%$ of that in WT mice and that UCP1 was undetectable in KO mice (Fig. 4B). Body surface temperature was measured in a $23^{\circ} \mathrm{C}$ condition for $15 \mathrm{~min}$ (Fig. 4C). When pups were taken from the nest, the initial body surface temperature was not statistically different among the genotypes, although it tended to be lower in Hetero $\left(32.1 \pm 1.1^{\circ} \mathrm{C}\right)$ and $\mathrm{KO}\left(31.2 \pm 0.4^{\circ} \mathrm{C}\right)$ mice compared to WT mice $(33.9 \pm$ $0.6^{\circ} \mathrm{C}$ ) (Fig. 4D). In the $23^{\circ} \mathrm{C}$ condition, WT and Hetero mice kept their temperature for at least $15 \mathrm{~min}$ (Fig. 4C). In contrast, the body surface temperature of $\mathrm{KO}$ mice gradually dropped by $2.4 \pm 0.2^{\circ} \mathrm{C}$ in 15 min and was significantly different from WT and Hetero mice (Fig. 4E). These results indicate that UCP1 is indispensable for the maintenance of body temperature in suckling mice.

\section{DISCUSSION}

In this study, to evaluate the role of BAT thermogenesis in body temperature control in pups in a non-cold environment, we examined the body temperature in two model animals that are deficient in BAT thermogenesis ability. In hamsters, consistent with 
A $23^{\circ} \mathrm{C}$

Day7

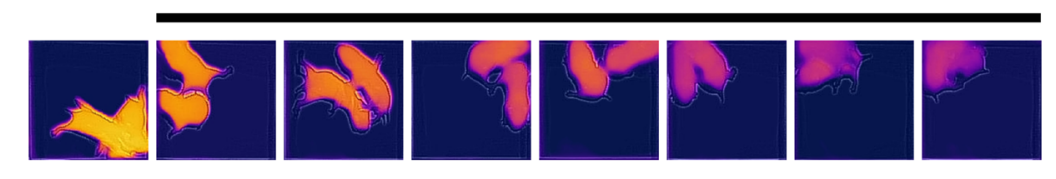

Day10<smiles>[10BH]</smiles>
$\mathbb{2}^{\mathrm{IR}}$
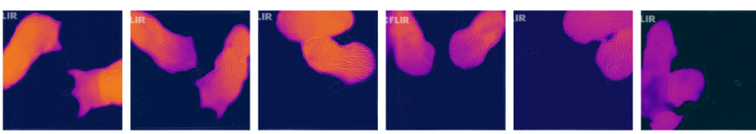

$40^{\circ} \mathrm{C}$

Day14
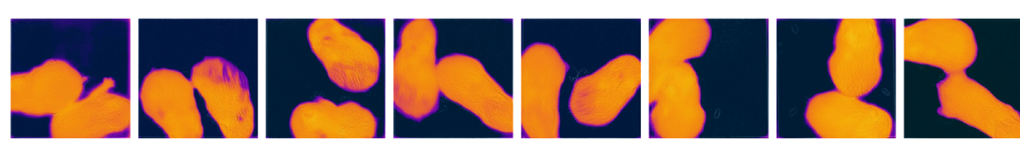

10

12

$14 \quad 20^{\circ} \mathrm{C}$

(min)

B

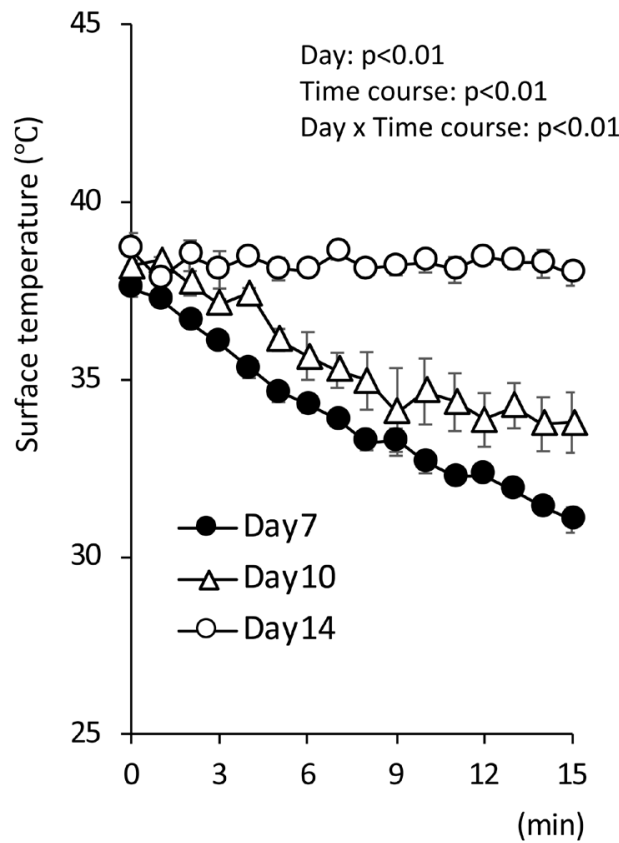

C

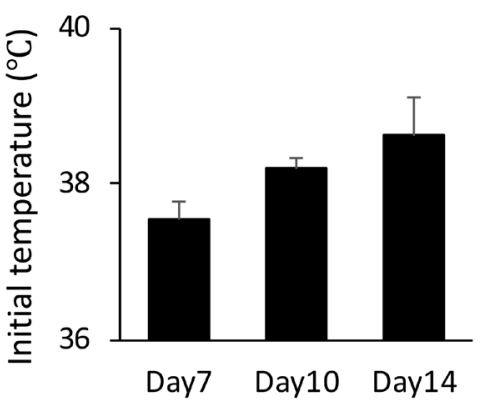

D

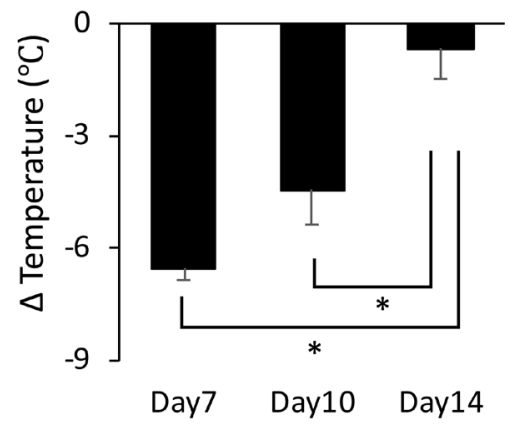

Fig. 3. Body temperature control in 7 to 14-day-old hamsters. At the indicated day, pups were taken from the nest and put on a thermal plate kept at $23^{\circ} \mathrm{C}$. The surface temperature was monitored by infrared camera every $1 \mathrm{~min}$ for $15 \mathrm{~min}$. Typical changes in surface temperature are shown in (A), and the quantified data are shown in (B). Initial body surface temperature (C) and temperature change in 15 min (D) were compared among the hamsters at different postnatal days. Values are expressed as mean $\pm \mathrm{SE}(\mathrm{n}=4$ per group, two-way analysis of variance followed by the Tukey's honestly significant difference post-hoc test, $* P<0.05)$.

our previous study $[14,16]$, interscapular fat tissue was gradually converted from white adipose tissue to brown adipose tissue, and the UCP1-positive area were more than $80 \%$ of the tissue on day 14 , whereas it was as low as $18 \%$ on day 10 and scarcely detected on day 7 , respectively. When body surface temperature was monitored at $23^{\circ} \mathrm{C}$, day 7 and day 10 pups failed to maintain body temperature, whereas the temperature of day 14 pups was not changed for at least $15 \mathrm{~min}$. These observations are consistent with previous reports that the increase in oxygen consumption in response to norepinephrine injection [7] or cold exposure [19] was not observed before day 12 . Taken together, these results indicate that hamsters acquire the ability to maintain body temperature in parallel with BAT development.

In addition to thermogenesis, heat dissipation is also important for the regulation of body temperature. In hamster pups, the body weight increased $\sim 2$-fold from day 7 to day 14 , indicating a decrease in the heat dissipation because of the lowered ratio of body surface area to body mass. Thus, it is possible that the body temperature was maintained at day 14 because of the lower heat dissipation from the body surface. To examine the role of BAT thermogenesis in pups more clearly, we used mice deficient in 
A

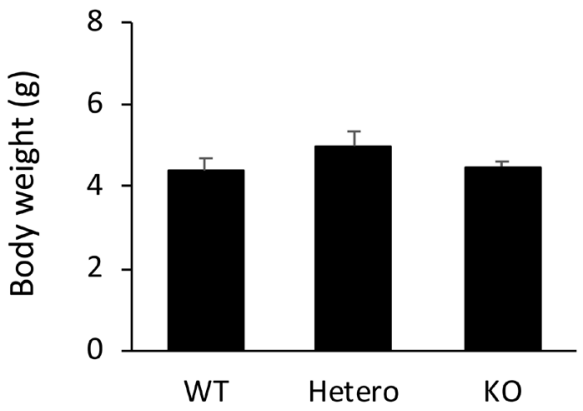

C

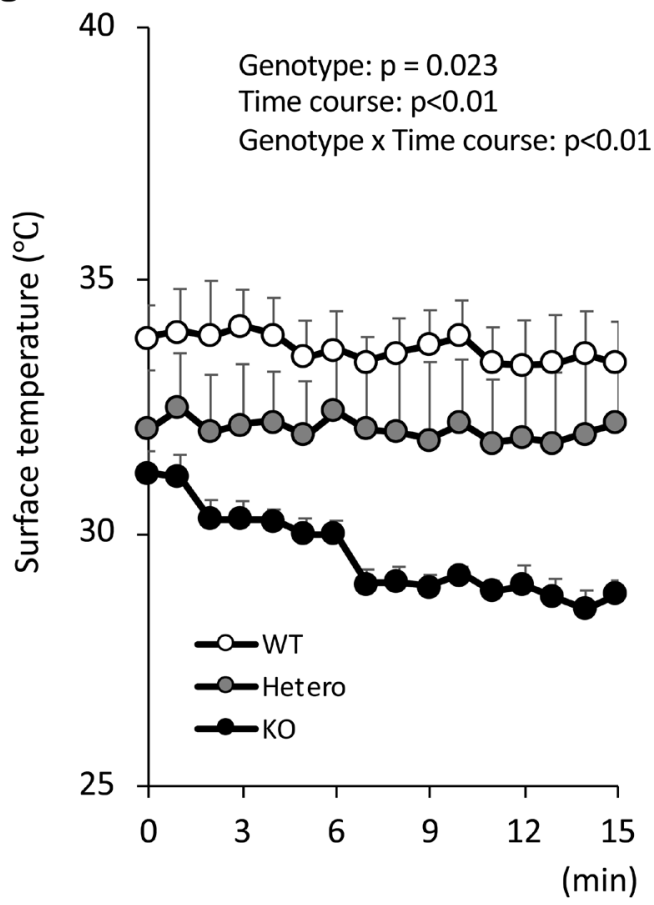

B

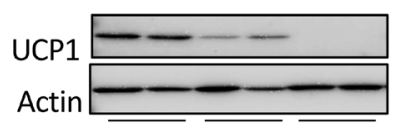

WT Hetero KO

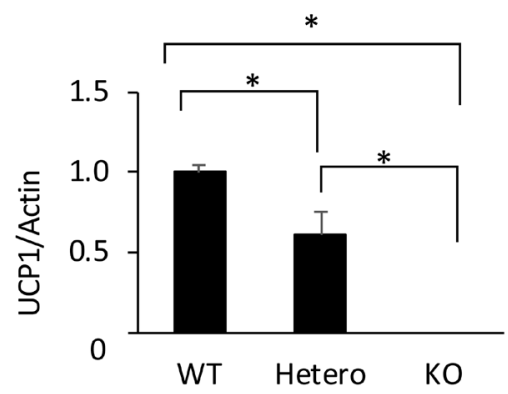

D

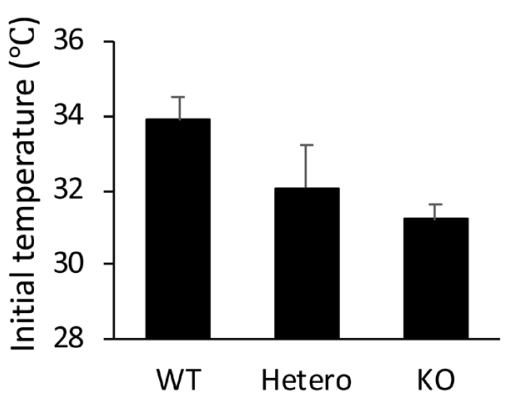

E

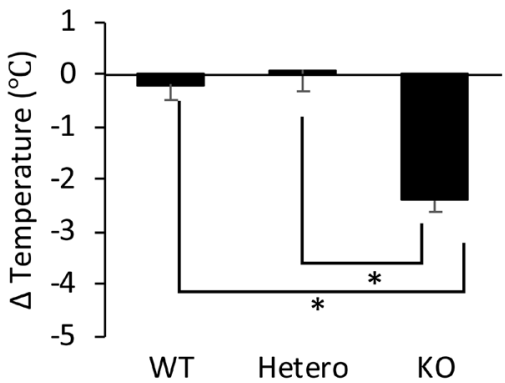

Fig. 4. Body temperature control in 12-day-old Uncoupling protein 1 (UCP1)-deficient mice. Body weight (A) and UCP1 protein level in interscapular brown adipose tissue (B) were measured in 12-day-old wild-type (WT), $U c p 1^{+/-}$(Hetero), and $U c p 1^{-/-}$(KO) mice. Pups were taken from the nest and put on a thermal plate kept at $23^{\circ} \mathrm{C}$. The surface temperature of the pups was monitored by infrared camera every 1 min for 15 min. Quantified surface temperatures are shown in (C). The initial body surface temperature (D) and the temperature change in 15 min (E) were compared among the genotypes. Values are expressed as mean $\pm \mathrm{SE}$ ( $\mathrm{n}=4$ per group, two-way analysis of variance followed by the Tukey's honestly significant difference post-hoc test, $* P<0.05)$.

$\mathrm{UCP} 1$. In the $23^{\circ} \mathrm{C}$ condition, body temperature was maintained in both WT and Hetero mice but not in UCP1-KO mice, indicating an indispensable role of UCP1-dependent BAT thermogenesis in the maintenance of body temperature even in a non-cold environment. Interestingly, Hetero mice retained body temperature in spite of a lower amount of UCP1 (61\% of that in WT mice). It is likely that the low UCP1 content in the BAT of Hetero mice was still enough to maintain body temperature in a non-cold condition. It is probable that the difference in body temperature among the genotypes would be clearer at cooler temperatures. It should to be noted that the body temperature of pups soon after picking up from the nest showed a tendency for an inverse correlation with UCP1 content both in hamsters and mice. It is likely that gathering with the dam and siblings in the nest is not enough to compensate for the absence of UCP1-dependent thermogenesis in both species.

It has been reported that hibernators, such as ground squirrels and Syrian hamsters, are cold-tolerant even in a non-hibernating state. Transient receptor potential cation channel subfamily M member 8 (TRPM8), a cold- and menthol-sensitive ion channel in somatosensory neurons $[12,18]$, of squirrel and hamster differs in several amino acids from that of the rat ortholog, and this results in the lower sensitivity to cold temperature [11]. In addition, it has been reported that neurons differentiated from induced 
pluripotent stem cells (iPS) cells made from ground squirrels tolerate a cold temperature of $4^{\circ} \mathrm{C}$ for $4 \mathrm{hr}$, whereas neurons differentiated from human iPS cells or primary cultured rat neurons showed microtubule destruction induced by mitochondrial stress-induced reactive oxygen species production and lysosomal membrane permeabilization upon cold stimulation [17]. Thus, the hamster, as a hibernator, is naturally resistant to cold stimulation. Indeed, in our study, the body temperature of 7-day-old pups dropped by $6^{\circ} \mathrm{C}$ during the 15 min experiment; however, there was no abnormality observed in the pups when returning them to the nest after the experiment. The cold-tolerance nature of hamsters may allow the lack of BAT in the early postnatal period in this species. As it has been reported in other species that ambient temperature is an important trigger of BAT maturation [1, 13, 15], it is possible that the late development of BAT in hamsters is due to their insensitivity to cold temperature. Further studies would be required to clarify the relation between ambient temperature and BAT development in hamsters.

In conclusion, BAT thermogenesis is indispensable for the maintenance of body temperature in pups of hamsters and mice, even in the non-cold circumstances. It is suggested that poikilothermy in early life and the acquisition of homeothermy thereafter is because of postnatal BAT development in hamsters.

ACKNOWLEDGMENTS. We thank Dr. Teruo Kawada (Kyoto University) for the kind gift of the anti-UCP1 antibody. This study was supported by JSPS KAKENHI Grant Numbers 17K08118 and 18H02274.

\section{REFERECES}

1. Adamsons, K., Blumberg, E. and Joelsson, I. 1969. The effect of ambient temperature upon post-natal changes in oxygen consumption of the guinea-pig. J. Physiol. 202: 261-269. [Medline] [CrossRef]

2. Arjamaa, O. and Lagerspetz, K. Y. H. 1979. Postnatal development of shivering in the mouse. J. Therm. Biol. 4: 35-39. [CrossRef]

3. Bal, N. C., Maurya, S. K., Sopariwala, D. H., Sahoo, S. K., Gupta, S. C., Shaikh, S. A., Pant, M., Rowland, L. A., Bombardier, E., Goonasekera, S. A., Tupling, A. R., Molkentin, J. D. and Periasamy, M. 2012. Sarcolipin is a newly identified regulator of muscle-based thermogenesis in mammals. Nat. Med. 18: 1575-1579. [Medline] [CrossRef]

4. Cannon, B. and Nedergaard, J. 2004. Brown adipose tissue: function and physiological significance. Physiol. Rev. 84: 277-359. [Medline] [CrossRef]

5. Cinti, S. 2005. The adipose organ. Prostaglandins Leukot. Essent. Fatty Acids 73: 9-15. [Medline] [CrossRef]

6. Enerbäck, S., Jacobsson, A., Simpson, E. M., Guerra, C., Yamashita, H., Harper, M. E. and Kozak, L. P. 1997. Mice lacking mitochondrial uncoupling protein are cold-sensitive but not obese. Nature 387: 90-94. [Medline] [CrossRef]

7. Hissa, R. 1968. Postnatal development of thermoregulation in the Norwegian lemming and the golden hamster. Ann. Zool. Fenn. 5: 345-383.

8. Iwanaga, T., Kuchiiwa, T. and Saito, M. 2009. Histochemical demonstration of monocarboxylate transporters in mouse brown adipose tissue. Biomed. Res. 30: 217-225. [Medline] [CrossRef]

9. Ikeda, K., Kang, Q., Yoneshiro, T., Camporez, J. P., Maki, H., Homma, M., Shinoda, K., Chen, Y., Lu, X., Maretich, P., Tajima, K., Ajuwon, K. M., Soga, T. and Kajimura, S. 2017. UCP1-independent signaling involving SERCA2b-mediated calcium cycling regulates beige fat thermogenesis and systemic glucose homeostasis. Nat. Med. 23: 1454-1465. [Medline] [CrossRef]

10. Kajimura, S. and Saito, M. 2014. A new era in brown adipose tissue biology: molecular control of brown fat development and energy homeostasis. Annu. Rev. Physiol. 76: 225-249. [Medline] [CrossRef]

11. Matos-Cruz, V., Schneider, E. R., Mastrotto, M., Merriman, D. K., Bagriantsev, S. N. and Gracheva, E. O. 2017. Molecular prerequisites for diminished cold sensitivity in ground squirrels and hamsters. Cell Reports 21: 3329-3337. [Medline] [CrossRef]

12. McKemy, D. D., Neuhausser, W. M. and Julius, D. 2002. Identification of a cold receptor reveals a general role for TRP channels in thermosensation. Nature 416: 52-58. [Medline] [CrossRef]

13. Mouroux, I., Bertin, R. and Portet, R. 1990. Thermogenic capacity of the brown adipose tissue of developing rats; effects of rearing temperature. $J$. Dev. Physiol. 14: 337-342. [Medline]

14. Nagaya, K., Okamatsu-Ogura, Y., Nio-Kobayashi, J., Nakagiri, S., Tsubota, A. and Kimura, K. 2019. Effect of ambient temperature on the proliferation of brown adipocyte progenitors and endothelial cells during postnatal BAT development in Syrian hamsters. J. Physiol. Sci. 69: 23-30. [Medline] [CrossRef]

15. Obregón, M. J., Jacobsson, A., Kirchgessner, T., Schotz, M. C., Cannon, B. and Nedergaard, J. 1989. Postnatal recruitment of brown adipose tissue is induced by the cold stress experienced by the pups. An analysis of mRNA levels for thermogenin and lipoprotein lipase. Biochem. J. 259: 341-346. [Medline] [CrossRef]

16. Okamatsu-Ogura, Y., Nio-Kobayashi, J., Nagaya, K., Tsubota, A. and Kimura, K. 2018. Brown adipocytes postnatally arise through both differentiation from progenitors and conversion from white adipocytes in Syrian hamster. J. Appl. Physiol. 124: 99-108. [Medline] [CrossRef]

17. Ou, J., Ball, J. M., Luan, Y., Zhao, T., Miyagishima, K. J., Xu, Y., Zhou, H., Chen, J., Merriman, D. K., Xie, Z., Mallon, B. S. and Li, W. 2018. iPSCs from a hibernator provide a platform for studying cold adaptation and its potential medical applications. Cell 173: 851-863.e16. [Medline] [CrossRef]

18. Peier, A. M., Moqrich, A., Hergarden, A. C., Reeve, A. J., Andersson, D. A., Story, G. M., Earley, T. J., Dragoni, I., McIntyre, P., Bevan, S. and Patapoutian, A. 2002. A TRP channel that senses cold stimuli and menthol. Cell 108: 705-715. [Medline] [CrossRef]

19. Rink, R. D. 1969. Oxygen consumption, body temperature, and brown adipose tissue in the postnatal golden hamster (Mesocricetus auratus). J. Exp. Zool. 170: 117-123. [Medline] [CrossRef]

20. Rafael, J. and Heldt, H. W. 1976. Binding of guanine nucleotides to the outer surface of the inner membrane of guinea pig brown fat mitochondria in correlation with the thermogenic activity of the tissue. FEBS Lett. 63: 304-308. [Medline] [CrossRef]

21. Smalley, R. L. and Smalley, K. N. 1967. Brown and white fats: development in the hamster. Science 157: 1449-1451. [Medline] [CrossRef]

22. Ukropec, J., Anunciado, R. P., Ravussin, Y., Hulver, M. W. and Kozak, L. P. 2006. UCP1-independent thermogenesis in white adipose tissue of cold-acclimated Ucp $1^{-/-}$mice. J. Biol. Chem. 281: 31894-31908. [Medline] [CrossRef]

23. Ukropec, J., Anunciado, R. V., Ravussin, Y. and Kozak, L. P. 2006. Leptin is required for uncoupling protein-1-independent thermogenesis during cold stress. Endocrinology 147: 2468-2480. [Medline] [CrossRef] 